\title{
台湾の地すべり分布について
}

山口真 一*

\section{The Distribution of Landslides in Formosa}

\section{by Shin-ichi Yamaguchi}

著者が台湾大学物理学教室に滞在中，農林航空測量隊 が1966年12月に作製した台湾省各集水区概況図をみる機 会を得た。この図は全兒を林地, 草生地, 崩塌地, 可植 裸地, 不可植裸地, 水田, 早作地, 水面に分類してあ る。この国では未だ地すべり分布図が作られていないの で，この図面で地すべり分布図の代用ができないかどう か検討してみた。

崩塌地すべり地, 可植裸地を筋壊地と置き換えて集計 すると，それぞれ53力所, 38 力所となる。私の踏查した 白河水庫湛水域の地すべり，阿里山近傍の屏斜那の地す ベり，台北市西南部の地すべり，不門水庫の地すべり， 彰化市内の地すべりなどに該当する一対一の刘応地域が 見られないのが気にかかるが，この概況図は航空写真に よるもので，四中に取り上げられた崩塌地・可植裸地の 西積の最低は 50 ha であるので，現在は非常に大きい場 合についてのみ議論することになるのであろう。そうす ると崩塌地を大崩壊地, 可植裸地を古い崩垻地と解釈し たすがよいかも知れない。これらの場所の分布を台湾省
地質調査所が1953年に作った30万分の 1 の地質図に対比 してみた。

台湾の地質地形図をみると, 高山脈地带, 中山脈地 帶, 平野部が南北に続いて拉り, 地質も南北につながっ ているので地質による分類を行なっても，地形による分 類との差がはっきりしない。それで破砕带による影響を 検討してみた。破砕炗の中心線からの距離に応じて，崩 壊地の含まれる確率の変化する様子を表-1, 表- 2 に示 した。表ー1では破砕带の中心線よりの距離を增すと,

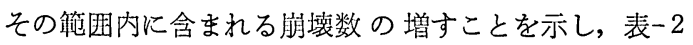
では破研带の中心線から龳ざかるにつれ，崩壊数の減る ことを示している。以上の様子を図-1 拈よび 2 に示し た。

この 2 つ表と 2 つ眓から次のことが推定される。

(1) 破磔带が大崩壊の発生数に影梁を及ぼしている。 また破砕带の中心線に近いほど，発生が密である (図-1)。

（2）破砕带の中心線より $1 \mathrm{~km}$ 以内の発生率は群を拢

表-1

\begin{tabular}{|c|c|c|c|c|c|c|c|}
\hline \multicolumn{2}{|c|}{$\begin{array}{l}\text { 破砕㛿の中心線 } \\
\text { より }\end{array}$} & 面 $\left(\mathrm{km}^{2}\right)^{\text {積 }}$ & 大崩壊数 & $\begin{array}{l}1 \mathrm{~km}^{2} \\
\text { 発生数 }\end{array}$ & 旧崩壊数 & $1 \mathrm{~km}^{2}$ 当りの & $\begin{array}{l}\text { 両者含わせて } 1 \\
\mathrm{~km}^{2} \text { 当りの発生数 }\end{array}$ \\
\hline $1 \mathrm{~km}$ & 以内 & 8,010 & 21 & 0.0026 & 13 & 0.0016 & 0.0042 \\
\hline $2 \mathrm{~km}$ & 以内 & 13,680 & 29 & 0.0021 & 16 & 0.0012 & 0.0033 \\
\hline $3 \mathrm{~km}$ & 以 内 & 18,180 & 34 & 0.0019 & 23 & 0.0012 & 0.0031 \\
\hline $4 \mathrm{~km}$ & 以内 & 21,420 & 39 & 0.0018 & 28 & 0.0013 & 0.0031 \\
\hline $5 \mathrm{~km}$ & 以内 & 24,660 & 43 & 0.0017 & 30 & 0.0013 & 0.0030 \\
\hline $6 \mathrm{~km}$ & 以内 & 27,000 & 46 & 0.0017 & 33 & 0.0012 & 0.0029 \\
\hline $7 \mathrm{~km}$ & 以 上 & 35,570 & 53 & 0.0015 & 38 & 0.0011 & 0.0026 \\
\hline
\end{tabular}

表-2

\begin{tabular}{|c|c|c|c|c|c|c|}
\hline $\begin{array}{l}\text { 破砕带の中心線 } \\
よ り\end{array}$ & 面 $\left(\mathrm{km}^{2}\right)^{\text {積 }}$ & 大崩壊数 & $\begin{array}{l}1 \mathrm{~km}^{2} \\
\text { 発生数 }\end{array}$ & 旧崩壊数 & $\underset{\text { 発生数 }}{1 \mathrm{~km}^{2}}$ 当りの & $\begin{array}{l}\text { 両者合わせて } 1 \\
\mathrm{~km}^{2} \text { 当りの発生数 }\end{array}$ \\
\hline $1 \mathrm{~km}$ 以 内 & 8,010 & 21 & 0.0026 & 13 & 0.0016 & 0.0042 \\
\hline $1 \mathrm{~km}$ 以上 $2 \mathrm{~km}$ 以下 & 5,670 & 8 & 0.0014 & 3 & 0.0005 & 0.0019 \\
\hline $2 \mathrm{~km}$ 以上 $3 \mathrm{~km}$ 以下 & 4,500 & 5 & 0.0011 & 7 & 0.0016 & 0.0027 \\
\hline $3 \mathrm{~km}$ 以上 $4 \mathrm{~km}$ 以下 & 3,240 & 5 & 0.0016 & 5 & 0.0015 & 0.0031 \\
\hline $4 \mathrm{~km}$ 以上 $5 \mathrm{~km}$ 以下 & 2,840 & 4 & 0.0014 & 2 & 0.0007 & 0.0021 \\
\hline $5 \mathrm{~km}$ 以上 $6 \mathrm{~km}$ 以下 & 2,340 & 3 & 0.0013 & 3 & 0.0013 & 0.0026 \\
\hline $6 \mathrm{~km}$ 以 上 & 8,570 & 7 & 0.0008 & 5 & 0.0005 & 0.0013 \\
\hline
\end{tabular}


地すべり Vol. 7, No. 3 (通巻 第23号)

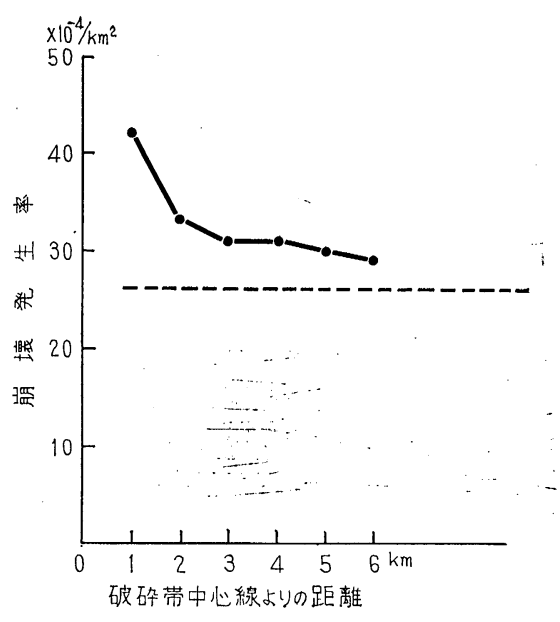

図-1 崩壊発生率の破碀带中心線よりの距離 による変化

表-3

\begin{tabular}{|c|c|c|c|}
\hline $\begin{array}{l}\text { 破砕帯の中心線 } \\
\text { より }\end{array}$ & ${ }^{\text {面 }}\left(\mathrm{km}^{2}\right)^{\text {積 }}$ & 旧崩壊数 & $\begin{array}{l}1 \mathrm{~km}^{2} \text { 当り } \\
\text { の発生数 }\end{array}$ \\
\hline $1 \mathrm{~km}$ 以 内 & 8,010 & 13 & 0.0016 \\
\hline $1 \mathrm{~km}$ 以上 $6 \mathrm{~km}$ 以内 & 18,990 & 20 & 0.0011 \\
\hline $6 \mathrm{~km}$ 以 上 & 8,570 & 5 & 0.0006 \\
\hline
\end{tabular}

いて高い。 $1 \mathrm{~km}$ 以上 $6 \mathrm{~km}$ 以内の発生率も, その 他に較べると，かなり高い(図-2)。

(3) 旧崩壊については数が少ないので表一 3 のごとく， 大まかに分けると，(1)，(2)と同じことがいえる。

(4) 日本の場合と比較するため, 破砕帯の中心線より の距離を $6 \mathrm{~km}$ とさめると, それの内側での発生率 は $0.0029 \mathrm{~km}^{-2}$, 外側では $0.0013 \mathrm{~km}^{-2}$ である。こ れは日本の場合の $0.043 \sim 0.032 \mathrm{~km}^{-2}$ と $0.0042 \mathrm{~km}^{-2}$ に較べ著しく小さい。

竹内・湊元 ${ }^{1)}$ によれば地すべりの数と面積の関係は

$\log N=4.08-1.42 \log A$

で示される。ここに $N$ は地すべりの数，A はへクター ルで示した面積である。ここで用いた地すべりの最小 面積が不明であるので $A_{0}$ とし, 日本の地すべりの数を 6000 とする

$$
\int_{A 0}^{\infty} \frac{10^{4.08}}{A^{1.42}} d A=6000
$$

計算の結果 $A_{0}=2.27$ となる。

台湾で統計した地すべりの大きさは 50ha 以上であっ たので $A_{0}=2.27$ 以上の数との比を求めると

$$
\frac{\int_{50}^{\infty} \frac{10^{4.08}}{A^{1.42}} d A}{\int_{2.27}^{\infty} \frac{10^{4.08}}{A^{1.42}} d A}=\frac{1640}{6000}=0.27
$$

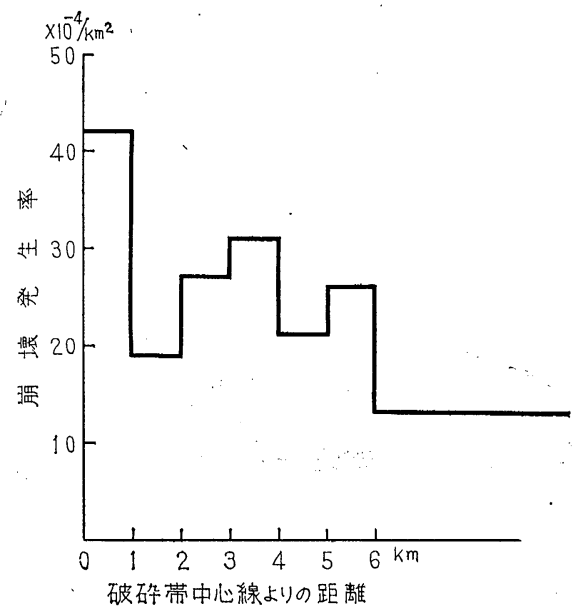

図-2 崩壊発生率の破砕帯中心線よりの距離 による変化

このことは日本において 50ha 以上の大きさのものだ けを統計すると数は1640個で発生率は0.27倍となること を意味する。したがって台湾でも同じ，地すべり数〜面 積の式が成り立つならば，50ha 以上の地すべりの発生 数に $1 / 0.27$ を掛けると $2.27 \mathrm{ha}$ 以上の発生数の推定值が 得られる。

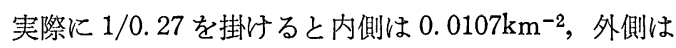
$0.0048 \mathrm{~km}^{-2}$ となり外側の発生率は日本とほとんど同じと なる。そうすると破砕帯の中心線より $6 \mathrm{~km}$ 以内の発生 率は日本の1/4〜1/3でその理由は今のところ分らない。

国際的な人間の交流，技術の交換が頻繁になるにつれ 用語の定義を明確にする必要がある。しかし現在は地す ベり地の定義ですらはっきりしない場合が多い。台湾の 崩塌地，可植裸地を地すべり地と置き換え，日本と同じ 「地すべり数と面積との関係」が成り立つと仮定すると 単位面積当りの発生数は日本とほとんど同じになった。

また発生率は破砕帯の影響を受けることも日本と同じ であるが，破砕帯での発生率は日本の $1 / 3 \sim 1 / 4$ に過ぎな かった。

資料の整理，統計をわずらわした小西利史技官，湊元 豪己技官に謝意を表したい。

\section{文献}

（1）竹内篤雄・湊元豪己; 統計からみた地すべり地の特 徵, 京大防災研年報 No. 11A (1968) 675 686

(2) 山口真一; 地すべりの素因と誘因について，地すべ り Vol. 4 No. 1 (1967) $4 \sim 11$ 